The Social Sciences 7 (3): 391-404, 2012

ISSN: $1818-5800$

(C) Medwell Journals, 2012

\title{
An Analysis of the Leasehold Concept in the Land Management System of Indonesia and Malaysia
}

\author{
Hermayulis, Frengki Hardian, Hernadewita, Dian Amelia, \\ Che Husna Azhari, Noor Inayah Yaakub and Rohimi Shapiee \\ Institute of the Malay Worlds and Civilisation (ATMA), \\ Universiti Kebangsaan Malaysia (UKM), 43600 Bangi, Selangor, Malaysia
}

\begin{abstract}
An analysis of leasehold concept in the investigation of the application of land management system and the features of the leasehold system in Indonesia and Malaysia which is predicated on independence of contract as a legal arrangement for land management and planning that encourages sustainable development. The approach is using analytical concepts of property rights under regulatory enactment applied in both countries and the innovation process. The researchers found the post-contractual imposition of statutory regulation of leasehold in land management system in Indonesia and Malaysia influence compliance to the leasehold system in achieving sustainability, the reinterpretation of statutory regulation in areas with a leasehold system and the reception of the land lease as a basis for innovations that help promote sustainable development. The researchers further develop the theory of planning by term of contract (lease) as an instrument of sustainable land management system in land development.
\end{abstract}

Key words: Leasehold, land management, development, lease, sustainable development, Indonesia and Malaysia

\section{INTRODUCTION}

The World Commission on Environment and Development (WCED) defines the concept of sustainable development as development that meets the needs of the present without compromising the ability of future generations to meet their own needs (WCED, 1987). The term sustainable land management has also become popular in an International Framework for Evaluating Sustainable Land Management report (FESLM) by Smyth and Dumanski (1993). Furthermore, the researchers have used this report as a guideline in embarking on and focusing this research on land enactment applied in both countries Malaysia and Indonesia.

In land management, the concept of sustainable development consists of sustainability and development (Auzins, 2004). The term sustainability is such that would not compromise the ability of future generations to meet their own needs and development means development that meets the needs of the present. In expressing the sustainability and development for land management systems, the researchers evaluated two criteria related to sustainable development. The 1 st criterion considers development. It is held that the land management system should enable and facilitate the development of land. The 2nd criterion concerns the relationship between land development and the environment. It is held that the system should be able to provide an institutional structure that facilitates solving problems in development and avoid unsuitability.

\section{LAND MANAGEMENT IN MALAYSIA AND INDONESIA}

Land management in Malaysia: The different races in Malaysia's plural society spread various attitudes towards land ownership through their customary acts and socio economics. These attitudes operate within a broader framework where the institution of private ownership of land exists. Ownership of urban land and therefore access to business opportunities have indeed become a major issue in South-East Asia's societies (Evers, 1984). The existing land laws in Malaysia and the system of registration which guarantees indefeasibility of title allows land to be leased, transferred and mortgaged. This eventually leads to the ability of land to be used as a symbol of wealth creation.

In rural areas, wide zones of land are owned by corporations for the cultivation of agricultural produce alongside small holders who own land for commercial

Corresponding Author: Hermayulis, Institute of the Malay Worlds and Civilisation (ATMA), Universiti Kebangsaan Malaysia (UKM), 43600 Bangi, Selangor, Malaysia 
production of crops and self consumption. Individual state governments in Malaysia put an emphasis on land use and since land is a state matter the status of urban land is important to the state. Increasing urbanisation has put pressure on land use and this has tended to create the problems of squatters, traffic and increased land values. Conflict between landlords and squatters prevail as rural urban migrants compete among themselves for urban land to take part in the higher income opportunities in the urban areas. In essence the poor in cities are shifted around and relocated through the dynamics of urban property development. There are numerous cases on conflict between them. Examples of such cases are on resettlement program for the community such as the Kampung Rumah Panjang (Rumah Panjang village) to the Flat of Seri Menanti in Klang and the resettlement of Setinggan Community in Selangor (Programmes of Setinggan Sifar by government of Selang or State in 2005). There has been a tendency towards rural/urban residential concentration by ethnicity (i.e., Chinese resident, Indian resident, Malay resident and also expatriate resident) in Malaysia, more than perhaps in any other country in South-East Asia. Furthermore, the state government in Malaysia through the New Economic Policy (NEP) and National Development Plans (NDP) has policies to diminish the imbalance by community resettlement. Thus, there are three issues on land that prevail in Malaysia: public power over land which include planning, development control, obligatory and public development; the land market which includes legal and fiscal frameworks for commercial transactions such as buying, selling, leasing and mortgaging and institutional structures to control land use and the general regulatory framework for decision making especially in urban land (McAuslan, 1982).

Land policy and planning: Policy is defined as a group of decisions taken by authorised decision-makers which can at least analytically be linked to some degree of coherence and which are concerned with the selection of prime goals and the means to achieve them (Gray et al., 1983). Land policy therefore provides the boundaries and parameters which provide the framework, direction and continuity of decisions made for the function of land in the implementation of national development plans which involve regional, statewide and local plans.

In Malaysia, land policy has been the result of various successive legislative documents which have been created to overcome numerous land-related issues. Therefore, an unambiguously documented national land policy is absent in Malaysia. This is perhaps somewhat due to the fact that since land is a state matter, each state has the prerogative of representing their own land policy. The constitution of Malaysia has the doctrine on private ownership of property including land. The National Land Code (KTN) supports this by the creation of an integrated and comprehensive system of land ownership, registration and dealing which ensures the indefeasibility of land titles. As stated, the right of land being a state matter is provided in the constitution. This means that there are as many land policies as there are states. Where the 3rd tier of government exists, i.e., local authorities, there exist further localised land policies which are in turn controlled by state land policies.

As land is a state matter it can be expected that each state will want to decide on what it can do with its land first rather than be subjected to a national policy. Thus, adoption of the land policy would be difficult if not impossible. Indeed, policy analysts have noted that the policy so formulated is merely directory in its affirmative aspects in so far as no method is known by which the legislative bodies of the state government could be required to enact specific legislative measures (Sheridan and Groves, 1967).

Since the inception of NEP, the federal government has emphasised on the contribution of NDP through urban based development and increased government participation (Talha, 1980). This is to achieve social and economic development based on the framework established by the NEP and NDP. The federal government is provided with considerable constitutional powers to undertake national development planning (Shafruddin, 1986).

Furthermore, the land use planning system introduced by the Town and Country Planning Act 1976 expresses the authority's intentions to encourage and control physical, economic, environmental and social changes in a particular area (Federal Department of Town and Country Planning, 1981). The structure plan and local plan system introduced by the 1976 Act would thus appear to have been established as the strategic planning which carries out the following functions (Bruton, 1982): translates national social, economic and physical policies and objectives into a physical development strategy for the state or parts of the state and provides the framework for the production of more detailed local land use plans to guide the agencies concerned with implementation.

The development planning framework that exists in Malaysia encompasses a wide range of bodies and agencies involved in the formulation, development and implementation of social, economic and physical policies and programmes of which land use planning is one (Singh and Gurjit, 1990). The position of land use planning in the country is therefore seen as essentially a 
subservien component within a wider and all embracing commitment to social and economic planning through national development plans (Bristow, 1985).

National Land Code 1965 (KTN): The main land law in Peninsular Malaysia is namely the National Land Code (KTN). The law was implemented starting from 1st January, 1966. From this date, an identifying system of land tenure was created for the eleven states in Peninsular Malaysia. Before 1966, the states had 2 different systems of land tenure. The states of Penang and Malacca had a land tenure system which was peculiar to the straits settlements which followed the English laws of property and conveyance whereby privately executed deeds were the basis of title to the land.

The states in Peninsular Malaysia are divided into 7 Sultanates, i.e., Johor, Kedah, Kelantan, Pahang, Perak, Selangor and Terengganu, Negeri Sembilan as an Elective Monarchy, Perlis as a Kingdom, Malacca as Bandar Melaka, Pulau Pinang as George Town and 2 federal territories, i.e., Putrajaya as federal administrative capital and Kuala Lumpur as Legislative capital. States capitals in parentheses are in Sabah and Sarawak and Labuan (federal territory). The states in Malaysia adopted a system based on the principle that private rights in land could be derived only from an express grant by the state or secondarily from the state registration of subsequent statutory dealings. The system applied in these states is known as the Torrens system of land title registration.

To abolish the different system in Penang and Malacca, the National Land Code Act was enacted in 1963 and brought into force at the same time as the KTN. Thus, today a uniform system of land law prevails in Peninsular Malaysia. The KTN was the result of the International Bank of Reconstruction and Development's effort in consolidating the various land laws prevailing in the country (BRD, 1995). The KTN achieved two objectives: it has established a uniform clear cut system of land tenure and dealing in place of a confused system and it has incorporated all those new provisions required to adapt the new system to the social and economic changes.

The KTN is based on the Torrens system of land registration and covers an extensive field in land tenure which provides for dealing in land, uses to which different classes of land could be put and land use planning. The system of conditional land titles is in essence a method of defining property. It establishes the duties and responsibilities of the government and private land holder with respect to individual properties. As land is a state matter, the KTN gives the state the authority to alienate land to prescribed entities either in perpetuity (free-hold) or for a term of years (lease-hold). Now, land can only be alienated for a maximum lease period of 99 years.
Free-hold alienations are possible only in exceptional cases. The individual land offices established throughout the states have strong control over land development. The control is derived from the authorisation conferred by the KTN and takes the form of land subdivision, imposition of special conditions, restrictions-in-interest and category of land use on land titles.

For leasehold land, conditions are normally imposed on the sale or transfer of such land. Legitimate permission of the state authority is required before leasehold land can be sold or transferred. This is to ensure that land is not transferred to foreigners and non-Malay individuals and companies freely in states where an implied policy exist to ensure that the local population retain ownership of land. Under the $\mathrm{KTN}$, land is categorised as agriculture or building or industrial. Each category of land has implied conditions and some have restrictions in interest.

A lot of land at the fringe of urban cities today was originally alienated as agricultural land and if these land owners want to develop their land to higher and better uses they have to apply to the land office for a change of land use category to either building or industrial.

There are mechanisms in the KTN which provide for periods for the preparation of the breach and even if the breach prevails the political ramifications can be enormous if forfeiture is carried out. The weakness, even if the forfeiture is done, is in the lack of flexibility of conditional titles to be put to other uses (Willcox, 1978). Land titles have positive and negative characteristics. A title describing the projected use or development which a land owner desires to undertake is seen as an overt encouragement to proceed. There is some participation by government in such activity.

Recently, amendments have been made to the KTN to prohibit the sale of land in the agricultural and building categories to foreigners. Foreigners can apply for 30 years leases on industrial land after obtaining permission of the respective state authority. This has been proposed in view of the growing concern by various state governments on the excessive purchase of land by foreigners who with their advantage of currency exchange are increasing land values much to the disappointment of locals. As it stands foreigners are required to conform to the strict guidelines of the Foreign Investment Committee (FIC) on investment and purchase of assets.

The recent amendments to the KTN give powers of decision to the state governments to decide on the ownership of land by foreigners. On the other hand the FIC is a federal government entity. There could be potential problems in having a common line of decision making as one entity could approve the application to purchase property while the other could reject it and vice versa. 
Land Policy of Penang and Malacca: Formerly, Penang and Malacca were part of the straits settlements created by British rule in Malaya. Therefore, the 1st land laws in these states were based on the English System of Grants in Penang and a combined system of English, Dutch and Malay land tenures in Malacca. By the 1960's the system of land tenure had become confusing. Furthermore, the National Land Code of Penang and Malacca Act were passed in 1963. Beginning in 1965, these land titles were changed from the former systems to the Torrens System.

There are special provisions in the 1963 Act which deal with customary land in Malacca. Customary land in Malacca which is subject to the category agriculture can only be transferred, charged or leased to a Malay who was born in Malacca or whose descendents were born in the state. However, in the case of customary land in Malacca which is subject to the category building or industry the above restrictions do not apply. The land policy here under customary tenure is to ensure such land remains in the hands of the Malays (the indigenous population).

Within Malacca, Malacca customary land is situated within prime areas of towns. Due to their limitations on ownership by non-Malays, development has bypassed these parcels. Realizing this, the Malacca state government has created a Malacca customary land company and its function is to develop customary land in Malacca. The scope of this company is that it will be able to sell the developed customary land to non-Malays on tenures of 30 years leasehold or less. An Amendment of Section 108 (1) (a) of the act has been tabled to Parliament.

On the subject of customary land, it is also pertinent to mention here that customary land also exists in the state of Negeri Sembilan and is governed by the Customary tenure enactment (Chapter 215). Under this law, dealings in respect of customary land can be affected only in favour of female members of the same tribe. On death, land is to be transmitted to the female heirs.

Land policy in Sabah: The Sabah land policy Chapter 68 provides the framework for land policy and also land registration based on the Torrens System. Land categorisation is put into 2 broad categories, namely town land and country land. The 4 pillars of land ownership in Sabah are:

- The state holds all estate and all others hold land from the state

- Ownership of estates in land comprises surface rights only. Minerals and materials are reserved for the state
- Possession is the root of title especially in claims of native customary rights

- Ownership of land is inheritable

Conditions and obligations of land owners are stipulated in Part 1 of the Ordinance. Section 31 creates implied conditions on all titles. Where land has been abandoned by the owner for 3 years or more, Section 36 of the ordinance provides for action to be taken against the owner.

Land Policy in Sarawak: Land policy in Sarawak was successively evolved by the Brooke family which introduced the Torrens System of land registration into Sarawak through various (land orders). Land law in Sarawak today is governed by the Land Code Chapter 81 . Land in Sarawak is classified into the following types:

- Interior area land is land not falling within other classifications and which is not a government reserve. This land can be declared a native area land only if the area consists of unalienated mixed zone land

- Native customary land comprises of land over which natives are entitled to exercise customary rights. This also covers lands which had been acquired by natives on the basis of a communal nature. Any area of state land can be declared a native communal reserve for the use of the native community. Native customary land also comprises interior area land over which a native has been permitted to acquire customary rights with the permission of the district officer. This is to prevent the possibility of excessive jungle clearance by the natives. Native area land is land held by a native under a document of title but does not include Mixed zone land. Any land can be declared native area land only if it consists of un-alienated mixed zone land

- Mixed zone land is land which is such by virtue of prior law or which becomes such by virtue of a declaration by the Minister under the code

Any privileges or rights under the native area land, native customary land or interior land can only be acquired by a native of Sarawak. The non-native is therefore limited to occupying and dealing with Mixed zone land. There is a prohibition on foreigners owning land. This extends to any person not a Malaysian citizen who is a permanent resident in the state and foreign companies, societies, association trusts or other bodies not registered in Malaysia. There is also an absolute prohibition on the issue of a document of title for an area of $>5,000$ acres. 
Land is liable to forfeiture if abandoned for 3 consecutive years or more. There are also various implied conditions where land is alienated for agricultural purposes. Such land cannot be used for other purposes and cultivation must be carried out with the whole area being brought under cultivation within prescribed periods.

Kelantan Land Enactment 1938: The Kelantan land enactment 1938 specifies that right, liberty, privilege, obligation or liability imposed or incurred in respect of land alienated under any such land law shall be subject to the provisions of this enactment.

The main expression in this enactment is focused on natives of Kelantan. A native of Kelantan means any person who falls within any of the following classes:

- Any person born in Kelantan whose father was a Malay

- Any person born in Kelantan whose mother was a Malay and whose father was a Muslim

- Any person wherever born whose father was a Malay born in Kelantan

- Any person wherever born both of whose parents were Malays and who has resided at least 15 years in Kelantan

- Any person who was born in Kelantan and whose father was also born in Kelantan

Environmental Quality Act 1974: While land use control remains the prerogative of local authorities, the federal government influences land use through the Department of Environment (DOE). The Environment Quality Act 1974 and the Environmental quality (Prescribed activity) (Environmental impact assessment). Order empowers the DOE to request for an Environmental Impact Assessment (EIA) for certain projects and activities.

As the requirement for an EIA covers a wide range of projects and activities, the EIA has become a major element in the approval of projects and activities. This has become even more critical in today's age of environmental degradation. Recently, the government indicated that it would be amending the Act to include provisions which will ensure that the EIA requirements will cover a wider net of projects.

Statutory organizations: The role of statutory organisations in the form of public enterprises in reducing inter-ethnic economic imbalance and promoting regional development was emphasized by the government (2nd Malaysia plan 1970-75); the necessity for such participation in the establishment and operation of a wide range of productive enterprises by the government arises from the aims of establishing new industrial activities in selected growth areas and creating a Malay commercial and industrial community.

In implementing land policy to pursue the above objective for a particular ethnic group, 2 public enterprises have played an important part namely the Urban Development Authority (UDA) and the State Economic Development Corporations (SEDC). The UDA was established in 1971 under the Urban Development Authority Act to translate government policy into a variety of programs aimed at restructuring society through urban development. It was given the task of weakening the dominance of the Chinese in the area of business and commerce by assisting the Malays to expand businesses through UDA's provision of business premises in the Chinese dominated commercial areas. The UDA could declare an area for development and obtain it without the approval of local authorities.

SEDC was formed in all states to carry out profitable economic activities. Hence, numerous industrial estates were established under the auspices of the SEDC's. SEDC also involved themselves in residential property development either through joint ventures with private land owners or on their own. Their land assembly was through compulsory acquisition of land from private individuals or through alienations from the state government. In residential projects both UDA and the SEDC's would allocate at least $30 \%$ of all housing units as low cost (costing $\leq \mathrm{US} \$ 11,600$ ) to provide housing for the low income group. They also ensure through administrative devices that at least $30 \%$ of all the housing units are reserved for the Malays.

Administrative controls: Numerous administrative controls have been imposed by the government to implement socio economic policies through land policy and land use planning. Nearly all state governments have made it a requirement for all property developers to ensure that at least $30-40 \%$ of land to be developed is reserved for low cost housing. Conditions also stipulate that $30 \%$ of all housing and commercial units must be sold to Malays and other indigenous peoples (Bumiputra). The units sold to Bumiputra are usually sold at price discounts ranging from $5-15 \%$ off the market price. There are occasions where special conditions are entitled on industrial land titles which require that at least $30 \%$ of labour employed in the industrial property are Bumiputra. In controlling the ownership of property by foreigners now-a-days, the government passed regulations that allow them to buy residential properties in high cost categories ( $\geq \mathrm{US} \$ 69,500$ ). In terms of land policy, this 
administrative device to an extent limited the foray of foreigners into the Malaysian property market to take advantage of the economical currency. There are mandatory fee discounts imposed to accommodate the Bumiputra and other races.

An administrative committee set up to regulate foreign investment into the country is, namely, the Foreign Investment Committee (FIC). So, the approval for any foreigner or foreign company wishing to invest in Malaysia has to obtained by making an application to the FIC. Of late the FIC has imposed the requirement on these foreign entities who wish to purchase high value properties, especially on commercial and industrial properties to incorporate with a local company to purchase the property and ensure that at least $70 \%$ of the company is owned by locals of which $30 \%$ must be Bumiputra. Here again, we see the implementation of broad sectoral policy through administrative devices to the issue of land ownership.

Land management in Indonesia: Indonesia, located in South-East Asia, is an archipelago with about 17,000 islands such as Sumatra, Java, Bali, Kalimantan, Sulawesi, the Moluccas Islands and Irian Jaya. There are 33 provinces within Indonesia from Sabang in Sumatra to Merauke in Irian Jaya.

Since 2001, the government of Indonesia and the Indonesian parliament through parliamentary decree and presidential decree (Perpres) 34/2003, consistent with the Law on Expropriation No. 20/1961 which has been invoked only once, have instructed the Land National Agency (BPN) to prepare a draft agrarian resource law to replace or modify the Basic Agrarian Law 5/1960 (or UUPA 1960). However, public consultation and government interdepartmental discussions led to the decision not to replace or modify the UUPA. The main objective of UUPA is to provide the foundation and details for: drafting other national agrarian-related laws; integrating and simplifying land law and ensuring land rights for all Indonesian people. These were the guidelines to BPN for drafting the land law within the framework of the already-established agrarian law. The land law should be prepared in a comprehensive manner to accommodate and manage all land-related issues and may intersect with other sectoral laws established under the UUPA. The UUPA discusses issues generally covered under land law, such as: land tenure; rights to land and land registration. It also stipulates that rights to land may be revoked for public interest by providing adequate compensation.

Further, UUPA states that the matter will be regulated through law which was the basis for the formulation of Perpres 36/2005 and 65/2006. It recognizes and protects rights acquired under customary and other laws that existed before promulgation of the UUPA. The proposed land law would support the provisions of the UUPA. It would be a subsystem of UUPA in the same manner as The Agricultural Law in 1961, The Foreign Investment Law in 1967, The Mining Law in 1967, The Forestry Law in 1999 and The Water Resources Law in 2004. These laws support the umbrella UUPA of 1960.

Basic Agrarian Law 1960: The Basic Agrarian Law No. $5 / 1960$ (UUPA 1960) is the foundation of land laws in Indonesia. Property and land rights of Indonesia are based on this UUPA. Below are the various land categories and principles of ownership that are frequently used. Currently under this law, there are 2 categories of land: Community land (Tanah Adat) is land belonging to a certain registered community where in 2 individual rights and 6 community rights can be eventually converted to a certified title.

Certified owned land (Tanah Hak Milik) is land belonging to an individual, registered under a local land agency and legally documented through a Notary. There are also five principles of ownership:

- $\quad$ Right of ownership (Hak Milik) (Part III, Article 2027); the right of ownership which can be sold, transferred, bequeathed and mortgaged to another individual. This is often referred to as Freehold land

- Right of exploitation (Hak Guna Usaha-GU) (Part IV, Article 28-34); the right to manage state-owned property for agriculture or husbandry for up to 35 years with the option of a 25 years extension. This certificate can be mortgaged

- Right of Building (Hak Guna Bangunan-HGB) (Part V, Article 35-40); the right to build on the property for up to 20-30 years with the option to extend. This right can be sold, transferred, bequeathed and mortgaged to another individual

- $\quad$ Right of Use (Hak Pakai) (Part VI, Article 41-43); the right to use of land for a specified period of time, usually a maximum of 10 years. This right cannot be sold, transferred, bequeathed and mortgaged to another individual, unless a special grant has been approved. This right is applicable to Indonesians, foreigners permanently domiciled in Indonesia or a foreign company with a representative office in Indonesia

- $\quad$ Right of Lease (Hak Sewa) (Part VII, Article 44-45); the right of lease is basically for right to lease land for building a property. The right of lease is the right in transacted between the lessee and the lessor and can be properly officiated by a legal notary under local law. Lease periods vary with up to 25 years being usual and with an option to extend often being successfully negotiated 
Concerning acquisition of land in Indonesia, several laws and regulations have been formulated for its implementation by each province. Thus, as in the implementation of UUPA 1960 in early 1960s, the different types of titles are associated with the purchase of land in this country. Foremost is Hak Milik, otherwise known as freehold title. This type of title could be held only by a national of Indonesia. Further, property ownership with this title is considered the most complete form of land ownership and it possesses complete right to exchange, sell, bequeath or transfer to eligible recipients.

Certain restrictions have been imposed on foreigners to buy land in Indonesia. A foreigner cannot purchase land outright in Indonesia. However, 3 options are open for non-Indonesians to buy or acquire land in the country, such as, leasehold investment, Indonesian nominee by power of attorney agreement and PMA Foreign Investment Company Structure.

Leasehold investment provides complete protection to a non-resident investor during the term of lease agreement which is prepared for a specific period, usually extending up to 25 years. Mostly, there would be options for extension. This agreement is also inclusive of the foreign investor's options regarding the right for the land or building renovation or demolition. Land or property acquired through this option holds a kind of title known as Hak Pakai or leasehold title.

In the case of Indonesian nominee who has power of attorney, a foreign investor can enter a legal agreement through a nominee who is a permanent resident of the nation. Thus, this nominee is put as registered owner and the land certificate is cleaved to the foreigner. On purchasing the property, both nominee and investor have signed a legal power of attorney. Once the power of attorney is signed, all of the nominee's rights with regard to property are waived and the investor is given complete right on the property. Accordingly, the investors can build, sell, mortgage or lease the property or they can even transfer the property to another party.

Administrative controls: As in Malaysia, the Indonesian government also imposes numerous administrative controls to implement socio-economic policies through land policy and land use planning. Nearly each province has made it a requirement for all property. An example is the Foreign Investment Company (or PMA) Structure which is primarily designed for enabling foreign business firms or corporations to purchase property in Indonesia. However, property acquisition does not provide complete ownership to foreign investors. This type of property acquisition holds the title of HGB.
The government offers foreign investors land rights that are relevant to the nature of their business. Prospective buyers of land for any purpose should consult the local government authorities on land use, planning and zoning. Based on a Perpres issued in June 1996, foreigners domiciled in Indonesia are allowed to own one residential property. To meet the regulations of ownership of a house or an apartment, a foreigner must be deemed to be beneficial to national development and must be either, an Indonesian resident (domiciled permanently in Indonesia) in possession of a permanent resident permit or a non-resident (domiciled in Indonesia only at particular times) in possession of appropriate visit and immigration stamps in his/her passport.

A foreigner can purchase or construct a house built only on land with the right of use (Hak Pakai), the right of use with the right of proprietorship or the right of lease (Hak Sewa). An apartment can only be purchased by a foreigner on land with right of use (Hak Pakai). Foreigners are not, however allowed to purchase houses or apartments classified as low cost housing or very lowcost housing, they are only allowed to purchase high cost housing, namely, housing units at cost $\geq \operatorname{US} \$ 25,000$.

Ownership is limited to 25 years (Governmental Decree No. 41/1996 or PP 41/1996) and is extendible for another 25 years and another 20 years provided that the foreigner remains an Indonesian resident or meets the status requirements. If the foreigner departs from Indonesia, the property must be sold or transferred within 1 year after departure. If the foreigner or his family does not use the house for $>12$ consecutive years then the foreigner forfeits the being domiciled status, for the purpose of owning residential property.

Among the procedures in connection with the buying of property in Indonesia are examination of land certificate at the Land office, payment of transfer tax by the salesperson at a commercial bank, payment of tax on acquisition of the land and building by the buyer, filing for company tax registration number with the local tax authorities, execution of sale and purchase of land deed through a legal representative appointed by an executive of the national land office, registration of the land deed in the name of the buyer with the Local Land Office and land deed at the tax on land and building office.

Amendment on land ownership: The house of representatives finally passed the proposed investment bill into law with the amendment aimed at replacing 2 separate 30 years old laws for foreign and domestic investors, Law No. 1/1967 and 6/1998, namely, the 2007 Investment Law which signals a much better investment climate than its predecessors. This is reflected in the following features: 
More certainty regarding land rights holding. Cultivation rights (HGU) are extended up to 95 years from previously 35 years. Building rights (HGB) may be obtained for up to 80 years from previously 30 years. Land use (Hak Pakai) rights are also extended from previously 25-75 years.

Simplified business related licenses subject to further detailed regulations. Applications for business related licenses will be served by the Investment Board of Investment (BKPM) under a one-stop service system. BKPM will act as a coordinator among government agencies, departments and regional administrations. Within the government, BKPM's position will also be elevated from being a part of the trade department to a non-departmental bureau responsible directly to the president.

Domestic and foreign investors are treated on an equal footing. Both groups will generally have the same access to any business areas despite the government requirement to reserve certain areas for small and medium enterprises and cooperatives. The government will publish a negative list in due course. This will contain some prohibited areas for investment oronly open under certain conditions. However, ifa business area is not on the list, investors can enter the area without restriction. At the moment, the negative list has not been issued yet.

Longer time for temporary stay permits and shorter time to get permanent ones. A temporary stay permit (KITAS) may be granted for up to 2 years, twice as long as the current standard. The new law allows a KITAS to be converted into a permanent stay permit (KITAP) after a 2 consecutive years of stay in Indonesia, much shorter than the current standard of 5 years. The removal of divestment requirement to local partners. Unlike its predecessor, the new law is utterly quiet about divestment requirement.

Statutory organisations of lease-hold in Indonesia: The role of statutory organisations in the form of public enterprises in increasing house ownership by middle class or below and promoting regional development was emphasised by the government (Ministry of Housing and Settlement of Indonesia) and the implementation should be based on the regional (or Town) of spatial planning (or RUTRW/RUTRK). The necessity for such participation in the establishment and operation of a wide range of productive enterprises by the government arises from the aim of establishing new industrial activities in selected growth areas.

In implementing land policy to pursue the above objective for the particular groups, the Ministry of Housing and Settlement has appointed the Department of
Regional Settlement and Infrastructure (or Kimpraswil), National Housing Agency (or Perumnas) and Real Estate Indonesia (REI) to take an important part in providing housing especially for the middle-class (and or lower class) socio-economic community. It was given the task of weakening the dominance of the high class society in the area of business and commerce by assisting the lower class to expand businesses through REI provision of business premises in the commercial areas.

In Indonesia, Kimpraswil was founded in 33 provinces to provide infrastructure for profitable economic activities. Kimpraswil also involved themselves in residential property development either through joint ventures with private land owners or on their own. Their land assembly was through compulsory acquisition of land from private individuals or through alienations from the state government. As in residential projects, the Ministry appointed Perumnas to focus on development of medium and low cost housing. Meanwhile, REI will take a part in providing housing for all socio-economic classes. In development of housing for society, REI should allocate at least $70 \%$ of all housing units as low cost (costing $\leq \mathrm{US} \$ 8,900$ ) to provide housing for the low income group. They also ensure through administrative devices that at least $20 \%$ of all the housing units are reserved for medium cost (US\$9,000 up to US\$24,900) and only $10 \%$ preserved for high cost units (cost $\geq \operatorname{US} \$ 25,000$ ).

Law of Environmental Management 1997: This law contains the norms of environmental law. Apart from this, this law will be a foundation for evaluating and adapting all laws and regulations which contain stipulations on the environment that is laws and regulations regarding irrigation, mining and energy, forestry, biological and ecosystem resource conservation, industry, human settlement, spatial ordering, land use and others.

Article 18 Section VI on environmental compliance requires that every business and/or activity which gives rise to a large and important impact on the environment must possess an environmental impact analysis to obtain the license to conduct a business and/or activity.

The license to carry out a business and/or activity must assert the obligations associated with compliance to stipulations in the environmental management field which must be implemented by the party responsible for a business and/or activity in carrying out their business and/or activity. For a business and/or activity which is obliged to make or implement an environmental impact analysis, the environmental management plan and monitoring plan which must be implemented by the person responsible for the business and/or activity must be included and clearly formulated in the license to carry 
out the business and/or activity. For example the obligation to treat waste, waste quality conditions for disposal to an environmental medium and obligations associated with waste disposal, such as the obligation to perform self-monitoring and the obligation to report the results of such self-monitoring to the responsible agency in the field of environmental impact control. Approval of this environmental impact analysis must be submitted together with the application for a license to carry out a business and/or activity.

Article 19 (point 1 and 2) clearly states that publication of the license to carry out a business and/or activity constitutes the realisation of the principle of administrative openness (or good governance). This public release of the license to carry out a business and/or activity allows public participation, in particular for those who have not used the opportunities available in the objections procedure, hearing and other aspects of the licensing decision making process. In issuing a license stated in article 19 to carry out a business and/or activity it is compulsory to take into account:

- Spatial management plans

- Public opinion

- Considerations and recommendations of authorised officials who are involved with such business and/or activity

As clearly stated in article 20 , the authority to issue or refuse a licensing application as provided for in (1) above lies with the Minister.

\section{ISSUES IN LAND MANAGEMENT SYSTEM OF MALAYSIA AND INDONESIA}

To promote the concept of sustainable development, the fundamental problem is to enable people to perceive that they have a future. In order to induce people to believe in the hope of a future and to plan for it in sacrificing present enjoyment, an enabling key is the provision of certainty. Certainty comprises of two meanings.

The first meaning is that the institution must continue for a period of time. The second meaning is that each institution should provide some degree of certainty to the parties involved. Such responses in managing certainty in land management systems arise from a number of problems faced by society from the impact of implementing sustainable development in their social life.

Property rights: In the state of Kelantan in Malaysia, a person who is stated as a Malay can live, work, marry, vote or even contest for a seat in the state legislative assembly. But there is one thing people not born in Kelantan will find difficulty, that is, in buying property in the state. They are restricted by an old state land law which requires people born outside Kelantan to fulfill several conditions before they can buy property. Firstly, the buyers must be Malays, as the majority of the land here is Malay reserve land. Then they must have resided in the state for at least 15 years. And to top it off, all transactions must be approved by the state executive committee. These conditions have deterred many Malays as non-Kelantan born people from buying a home. Kelantan is the only state in the country which practises this enactment. On the one hand a number of people interviewed expressed their agreement to continue this enactment to preserve land for natives of Kelantan. On the other hand, most of them said that this enactment should not be allowed to continue as this is double standards for all Malaysians in having a land or property in Kelantan. It is strange that people from Kelantan wanting to buy property in other states do not have to fulfill such conditions.

This law was believed to have been introduced in the 19 th century when Kelantan was a vassal to Siam. In 1900, the Kelantan Sultan sold a land concession to retired British officer Robert William Duff who owned Duff Development Company. However, the Sultan was ordered by the King of Siam to stop the sale, as he only had powers to endow the land to natives. The Kelantan Land Enactment 1938 defines natives as Kelantan-born Malays, Kelantan-born Malays with Malay mothers and Muslim fathers and Malays who were born outside the state but with their fathers being born here. Also under the group are Malays who have resided in the state for a minimum of 15 years and non-Malays who have lived in the state for generations.

\section{Lease-hold systems}

Lease-hold in Malaysia: There are imbalances in housing occupancy for Malays and other Bumiputra citizens. The government gives special treatment for them to have houses by giving a discount when they purchase property and this is not valid for other races in Malaysia. On the one hand, Bumiputra are allowed to have freehold title in property right and on the other hand, other races will only be allowed to have leasehold for a maximum period of right for 99 years.

There is a lack of affirmation for housing price between Bumiputra and the other races in Malaysia. For example, in purchasing residential units (house or flat), they can acquire a special price support by the government by $5-15 \%$ discount off the total price for low cost housing units but this is not applicable for non-Bumiputra. 
In this regard, the leasehold system can serve the purpose of striking a balance between certainty and the concern for the changing needs of society. With a prespecified lease period that characterises a leasehold interest, certainty is secured. The covenants of the lease are subject to review upon the expiry of the lease. The freehold system lacks such built-in balance. The presence of a pre-specified lease duration in a leasehold interest renders it superior to a freehold one in terms of sustainable land management.

It is, however, not easy to determine the optimum trade off between the provision of certainty and the requirement of taking into account public needs. Lessees usually prefer longer-term leases but this may not be desirable from the social and public administrative perspectives in view of financial implications and potential conflicts between private and public interests on land use. The optimum duration is more a matter of statutory administrative implementation and hence may also be regarded as a part and parcel of a Schumpeterian process. In the history of the leasehold system in Malaysia, the length of the lease period for building land has undergone several stages of changes and exhibited a wide range.

Generally, any dispute regarding the interpretation of the covenants between the government and the lessee can be settled by negotiation and as a last resort by the court. The certainty of terms and condition provides the lessee with the necessary inducement to plan for the future which is for sustainable land management. Developing of apartments is one of the best examples. The relationship of landlord and tenant exists among parties, there is privity of estate. This privity of estate concept goes beyond contractual relationships that bind the original parties to a contract. It determines the liabilities according to each party's relationship to the estate as created under the respective lease. Thus, the certainty of development rights is guaranteed even if there is a change in the ownership of the land. The development rights run with the land irrespective of its owners and the value of land is preserved as far as the amount of development rights is concerned. This induces the present owner to plan for the future.

In this regard, although the lease emerges as an agreement between the government and the lessee on a contractual basis, the parties who do not participate in but are affected by the lease are not excluded from the land administrative process. The UDA which is the executive arm of the Malaysian government for managing land, normally circulates each land grant/modification proposal to all relevant government departments including the respective district office for comments.
Lease-hold in Indonesia: According to the leasehold system in Indonesia, development planning in this sense is a matter of freedom of contract and there is no compulsion involved. It is a flexible arrangement as any subsequent permanent change to the lease is a matter of negotiation for a new contract or new lease through the lease modification process.

As the leasehold system of Indonesia provides a framework for the development of land, the development parameters under the lease, notwithstanding any subsequent statutory planning or building control interference are certain for a period of time. Bearing in mind that the Indonesia lease-hold system can facilitate the development of land by delineating private property rights under the market mechanism which is conducive to sustainable land management, an argument has further developed as below.

The BPN office in Jakarta and other related departments have to give due consideration to all opinions collected by the BPN district office before executing any land grant/modification. To address the concerns of the stakeholders, it is common that many development proposals would be altered as a result or certain conditions would be imposed/modified in the land grant documents. This circulation process provides a platform for exchanging ideas among key stakeholders. Parties can express their opinions based on their own interest, preference and expectation for future. This is also a means to ensure that the future development of the land can be accepted by the public. As a result, criteria considered necessary for sustainable development of land can be incorporated in the government lease at this stage. An example of this is a lease for mining operations under buffer zone on land forest. The stakeholders should have the legitimate permit from the mining department, forest and agricultural department and also department of internal affairs before starting mining operations.

In fact, this circulation process is also well justified in economic terms. The potential externalities of both the original land grant and any subsequent lease modification proposal can be identified through consulting the affected third parties. This enables the contracting parties to take full consideration of the costs and the benefits of the land grant and the development proposal. The conditions in government leases can also serve as simple and effective means to internalise the externalities. Examples of such lease conditions are clauses against offensive trade, for tree preservation and for landscaping. From the survey, some people criticise the leasehold system on the basis that externalities from a site can only be sorted out at the beginning of the land grant or in the event of an application of lease modification within the lease period. 
Bristow (1985) considered lease control as inflexible as lease conditions can only be inserted by the government during the land sale or on the occasion of any lease modification. This view point is based on two concerns:

- Social preference/needs may change over time

- The lessee may change the use of land to a socially undesirable one without breaching the existing covenants so that government can do nothing about it

The fixed lease period in the leasehold system provides a means to tackle the conflict. As explained earlier, a fixed lease period can balance the need for government to intervene in the light of changing needs and the need to provide incentives for private investment in real estate development. Some people may also criticize the present consultation method for being incomprehensive as it is only conducted at district level in most cases. While appreciating a territory-wise consultation can involve more people, one must also bear costs in mind the costs involved. The limitation placed on the number of participants and time in the circulation process is necessary to constrain the dissipation of resources due to the consultation process.

As stated in UUPA, any individual foreigner can own land in Indonesia with a status of Hak Pakai (Rights of Usage) or through leasehold. The Hak Pakai can be applied to either government land or Hak Milik (Title to land). Only Indonesian citizens may own land with the title of Hak Milik. Hak Pakai is similar to leasehold.

The UUPA states ownership is only for an Indonesian citizen or a company which complies with Indonesian law and is established in this region. Further, foreign ownership of land is dependent on the needs. When the purchasers are two people or more, the HGB (Right to Building) is particularly suitable but setting up a PMA company is a must, without it the status is only Hak Pakai. But it will be useful when the land is wide enough to be sub-divided. It is also suitable if the purchaser is a single person. However, both statuses are harmless for foreigners. It means that the Hak Pakai and the HGB may only be applied to the land of the Indonesian citizen with Hak Milik status. Since the Hak Milik is a title given only to Indonesian citizens, the preeminent way to protect foreigner's property is by HGB, whereby the rights/hak of the landowner are released to the other.

Since the foreigner has no title to the land in Indonesia, then the owner's Hak Milik could be transferred into HGB by several legal mechanisms. Most banks in Indonesia accept both rights, although there may be some differences in policy among them.

Land acquisition and resettlement: During the infrastructure summit held in Jakarta in January 2005, the Minister of Finance and National Planning and Development Agency (or BAPPENAS) noted that land acquisition and resettlement remains one of the main causes of delay in project implementation and disbursement. This position was echoed by representatives of other government agencies attending the summit and is confirmed as this appears to be caused by: lack of an updated legal framework guaranteeing equitable and rapid Involuntary Resettlement (IR); absence of comprehensive implementing regulations for IR and inadequate capacity for IR tasks.

The national legal framework covering IR matters has been strengthened since May, 2005. Decrees Perpres $36 / 2005$ and Perpres 65/2006, as well as BPN regulations on implementing Perpres 36/2005 and Perpres 65/2006, were significant improvements. However, they fall short of ensuring compensation, resettlement and livelihood restoration for all impacts caused by a project. The overall policy objective of these decrees and regulations is compensation alone to restore or improve social and economic conditions and only for people with land titles or traditional or customary rights.

The absence in the national legislation of broad and mainstream implementing regulations for $\mathbb{R}$, together with insufficient impact assessment capacity of local governments, results in unsystematic IR planning procedures, preparation, financing and implementation at the local level. Ultimately, this delays project implementation significantly. The lack of any legal provision for informal occupants and only ad hoc provision of nominal and inadequate assistance to informal dwellers by district governments also results in long delays in reaching agreements on development partner-financed projects that require restoration for all affected people.

The challenge of IR in Indonesia is a significant constraint to promoting investment in infrastructure with toll roads being one of the most difficult areas. Perpres $36 / 2005$, as amended by Perpres 65/2006 and BPN regulation $3 / 2007$ will serve as the interim legal framework for IR until the proposed land law is issued with the intention of replacing them by full coverage of land acquisition and resettlement provisions to enhance immovable property rights generally for all people in Indonesia. 
The statutory planning impact: As mentioned, the introduction of statutory planning has radically changed the institutional framework for land management in Indonesia. This radical change has implications for various aspects of use of land resources. While there is no argument that statutory planning could bring certain benefits to society, these benefits or planning gains do not come without costs. The introduction of statutory planning has particularly attenuated the private property rights over land and has impeded the features of the leasehold system in providing certainty and adaptability as a means to attaining sustainable development.

Reduction in certainty: The taking of private property rights without compensation tends to result in the government's excessive use and occupation of private property as stated by Anderson and McChesney (2003). Furthermore, Fischel suggested that compensation can serve as a benefit-cost discipline to guide the government regarding its actions. In the absence of compensation, it is unlikely that land resources can be allocated efficiently and with a degree of public acceptability, thus the chance of arbitrary zoning increases. This would cause economic impairment to the development market.

An example of a problem case not un-common in Malaysia and Indonesia is that of a residential building lot with an existing building which is zoned for road use under the statutory town plan. The government may not have any obligated public works programme to accomplish the road scheme proposed and the land affected has not yet been resumed by the government. When the scheme is announced, the development potential of the lot affected is exhausted. In this case, major renovation of the existing building involving the approval of building plans or redevelopment of the residential use is virtually impossible as:

- House or building is not permitted as of right under the relevant statutory town plan

- It is unlikely that the planning authority would grant planning approval for house or building use

These factors will tend toward an under-utilization of land resource and faster deterioration in the building stock. This result is clearly not compatible with the concept of sustainable development on land management system. In fact, the root case for this example is the lack of compensation for zoning area. The planning authority is required to pay for zoning activity. The preserve of compensation can serve as a practical measurement for the gains and losses arising from zoning. It can be imagined that a number of cases of the kind described above would occur. However in the lack of compensation, the efficacy of this zoning policy is uncertain.
The lack of compensation in statutory planning is often backed by claims that there is a lack of government funds. Without compensation, the gains of parties from the zoning area come from losses suffered by the individual lessees of the land down-zoned. In tackling the interface problems between a development project and its environment, statutory zoning is usually justified in the name of public interest. It is thus both just and equitable for society to pay for its preferences and so the compensation for zoning area should come from the public offer. This can ensure that each zoning action really addresses the needs of society and prevents zoning from becoming an arbitrary system of wealth redistribution.

The unilateral attenuation of private property rights without compensation reduces certainty in a land market designated on the leasehold system and affects the utilisation of land in both economic and environmental issues. To make the situation worse, a statutory town plan does not remain unchanged after its issue. It can be amended indefinitely in accordance with the procedures arranged by the TPO (in Malaysia) and RUTRW/RUTRK (in Indonesia) and also the date of the next revision is not legally constrained. When the notice of a new statutory town plan is made in the government gazette, it supersedes the pre-existing one.

\section{CONCLUSION}

Land policy in Malaysia and Indonesia is the result of land related instruments which more than adequately administer and control land use and development for compliance with national development objectives. The environment for the implementation of land policy and land use planning strategies is controlled by an embarrassment of regulations. Hence, it would not be incorrect to say that it is over regulated.

An institution has to enable people to form a view of the future to encourage sustainable development. In addition, the institution should provide a policy for changing plans and enable the efficient adaptability of the resource being managed as to reach a socially accessible outcome.

Sustainable land management combines technologies, policies and activities aimed at integrating socio-economic principles with environmental concerns so as to simultaneously maintain or enhance production/services, reduce the level of production risk, protect the potential of natural resources and prevent degradation of soil and water quality, be economically viable and socially acceptable. The leasehold system in 
Malaysia and Indonesia has exhibited all the above institutional features that are conducive to sustainable land management. First, the operation of the leasehold system as a town planning system is based on a market mechanism predicated upon the freedom of contract. This provides an effective framework for investments in and the development of land. Second, without sacrificing certainty, there is a mechanism for land resource re-allocation during the lease term. Land resource can be put under different uses at different times, as permitted by the government according to changing needs. Third, a government lease is a simple and effective means to internalize externalities arising from the development and use of land because the covenants of the lease can be drafted in ways to tackle interface problems between the development of land and the environment.

The National Land Code applied in Malaysia provides (Sections 14, 435 and 455) for the state governments to draw up individual state land rules. These rules outline the various procedures pertaining to land in the particular state. KTN is based on the Torrens system (British System). Indonesia applies the Agrarian Law No. 51960 based on the Dutch system. This includes procedures for the application for land from the state, permit applications to remove rock material and the premium rates for conversion for conversion of land use categories.

\section{IMPLIMENTATIONS}

An important feature of land policy and land use planning implementation in Malaysia is the effort to improve the economic base of the Malays. The attitude towards foreign ownership of land is also changing with increasing attention being paid to the diseconomies being created by speculation and increasing land values. Administrative controls such as those imposed by the Foreign Investment Committee play an important role in the control of foreign land ownership and hence foreign investment which has enormous spin-offs on other sectors of the economy. A major consideration in the effective implementation of land policy and land use planning is the fact that land is a state matter. It is interesting to note that whilst there exist various pieces of land legislation applicable to the country as a whole, each state eventually decides what is best for itself. In some instances this can be seen as an obstacle to national development and uniformity of policy implementation.

It is apparent that the land policies evolved from the various legislative instruments have not considered the issue of sustainable development and management of resources in detail. Now-a-days, it is essential for the government to seriously look into implementing of sustainable development and resources management in all land related legislation. This will also align the overall policy with the NDP (in Malaysia) and the RUTR (in Indonesia) where one of the main aspects is to give adequate attention to environmental protection. It is also necessary for the government to seriously consider a regulatory audit of all legislation and administrative regulations which affect the property development process especially housing. However, it must be borne in mind that the diseconomies created by stiff procedures and systems will also affect the flow of investments into the states.

The statutory planning system that is applied to the private land of Indonesia has compromised the built-in features of certainty and adaptability of the leasehold system and is thus problematic in terms of sustainable development. While statutory planning is sometimes unavoidable in the public interest, a practical mechanism for measuring and analysing the cost and benefits of the statutory zoning actions is currently lacking in Malaysia and Indonesia. Thus, compensation for depreciating planning decisions should be introduced as an efficient measure of zoning plan and also as a remedy for the reduction in certainty and/or property value caused by statutory zoning.

\section{REFERENCES}

Anderson, T.L. and F.S. McChesney, 2003. Property Rights: Cooperation, Conflict and Law. Princeton University Press, Princeton, NJ.

Auzins, A., 2004. Institutional Arrangements: A Gate Towards Sustainable Land Use. Nordic J. Surveying Real Estate Res., 1: 57-71.

Bristow, M.R., 1985. Some problems of methodology transfer: Strategic planning in Malaysia and Hongkong. Built Env., 11: 294-303.

Bruton, M.J., 1982. The Malaysian planning system: A review. Third World Plann. Rev., 4: 315-315.

Evers, H.D., 1984. Urban land ownership, ethnicity and class in South East Asia. J. Urban Regional Res., 8: 481-496.

Federal Department of Town and Country Planning, 1981. Development plans: A manual and functions form and content. Kuala Lumpur Federal Department of Town and Country Planning.

Gray, C.J., J.K. Stringer and P. Williamson, 1983. Policy change: An analytical framework. Annual PSA conference, University of Newcastle. April 1983. 
IBRD, 1995. 1995 world development report. Workers in an integrating world. Washington (DC), International Bank for Reconstruction and Development, pp: 276.

McAuslan, P., 1982. The urban land question. Habitat Int., Vol. 6, Issue $5 / 6$.

Shafruddin, B.H., 1986. The Federal factor in Government and Politics of Peninsular Malaysia. Oxford University Press, Singapore.

Sheridan, L.A. and H.E. Groves, 1967. The Constitution of Malaysia. Oceana Publications, New York.

Singh and Gurjit, 1990. Towards a theory of implementation in urban planning for public housing based on the Kuala Lumpur experience. Paper presented at the International Workshop on Asian Urban Land Policy, Kuala Lumpur.
Smyth, A.J. and J. Dumanski, 1993. FESLM: An international framework for evaluating sustainable land management. World Soil Resource Report, Food and Agricultural Organisation of the United Nations. http://www.fao.org/docrep/T1079E/T1079E00.htm.

Talha, M., 1980. Policy formulation and institutional building for public housing in peninsular Malaysia. Ph.D. Thesis, University of Wisconsin, Madison USA.

WCED, 1987. Our Common Future. Oxford University Press, Oxford.

Willcox, D.I., 1978. New planning wine in old legal bottles: The case for greater utilization of existing legal resources in Malaysia. Urban Law and Policy No. 1. 